\title{
Meta-Analysis on the Attitudes of Active Teachers About the Use of Educational Technology According to Gender
}

\author{
Francisco D. Guillén-Gámez \\ University of Cordoba, Faculty of Education, Department of Didactics and School Organization, Spain \\ ORCID: 0000-0001-6470-526X \\ Raquel Rodríguez-Fernández \\ National University of Distance Education (UNED), Faculty of Psychology, Department of Methodology of \\ Behavioral Sciences, Spain \\ ORCID: 0000-0003-4488-0778
}

Received: 2 Sep 2021

Accepted: 18 Oct 2021

\begin{abstract}
Studies analysing and comparing the attitudes of teachers towards Information and Communication Technologies (ICT) based on gender have provided mixed results. In this work, we carried out a metaanalysis on gender differences in attitudes towards ICT, from a global perspective and exploring four dimensions: affective-emotional attitude, beliefs, self-efficacy, and mixed with each other. Through the collection of 55 studies providing 73 effect sizes based on a total sample of 21,325 working teachers, a negative effect was found, almost null ( $d=-0.0297)$ and not statistically significant. These results indicate that female teachers have a more positive attitude towards the educational use of ICT than male teachers. Independently, the dimensions affective-emotional attitude ( $d=-0.342)$, beliefs $(d=0.114)$, and selfefficacy $(d=0.273$ ) produced significant effect sizes, although with small effects. The analysis of moderating variables showed that different moderators intervene significantly in the variability of effect sizes: continental origin of the teachers (emotional and beliefs dimensions); teacher's workplace (dimension self-efficacy); type of publication (emotional dimension) and validity of the instruments (emotional and beliefs dimension). With this meta-analysis, it is possible to take another step towards a better measurement and explanation of the attitudes that teachers have towards the use of new technologies in educational contexts.
\end{abstract}

Keywords: technology, education, teacher, teaching, gender, meta-analysis, research methods

\section{INTRODUCTION}

Since the emergence of new Information and Communication Technologies (ICT) and the Internet, as well as with the different Research and Innovation Framework Programs of the European Union (Horizon Report), educational processes have been reversed and transformed, causing a major revolution whereby teachers must hold a favourable and positive attitude toward ICT in order to achieve significant and relevant learning in students (Marbán \& Mulenga, 2019; Njiku et al., 2019; Rodríguez-Hoyos et al., 2021).

The emergence of ubiquitous learning tools in higher education allows for more active learning, increasing debate, the exchange of ideas, immediate feedback, and easy access to digital content (Alvarado et al., 2020; Phan et al., 2021); consequently, the attitudes of male and female teachers towards these new educational technologies may vary. Given this context, and as stated by Edison and Geissler (2003, p.137), "Technology affects everyone as it changes the fabric of society... And... While technology increasingly affects everyone, 
not all individuals view this trend as positive". Thus, it is not entirely clear whether previous research findings on the attitude of teachers towards technology are still relevant data today as they could be obsolete.

The attitude towards educational technology has raised different questions for researchers about the relationship between culture and attitude towards technology. Some relate it to the cultural and environmental conditions surrounding the individual, which shape their attitudes towards ICT and, subsequently, their use (Azmi et al., 2021; Collis, 1999; Islahi, 2019; Li \& Kirkup, 2007; Zyad, 2016). In other words, there could be a symbiotic relationship between technology and society (Carpi \& lacus, 2021) since, "the creation of a technology does not occur in a vacuum but instead encompasses social and cultural phenomena" (Davies, 2004, p. 163).

Against this background, it is important to analyse the results of those studies that measure the attitudes only of active teachers towards technology, since the meta-analyses on this topic carried out by Whitley (1997), Liao (1999), and Cai et al. (2017) did not focus solely on active teachers, since they used different types of samples (elementary, secondary, and college students, employees, teachers, adults, and mixed samples, among others), so that it was not possible to identify a specific view of the attitudes towards technology of each group. Therefore, this study contributes to focusing exclusively on analysing gender differences, or the lack of thereof, in working teachers' attitudes toward educational technology.

\section{BACKGROUND}

The concept of attitude refers to an individual's behaviour regarding a particular issue, therefore it effects on a personal level (Njiku et al., 2019). Eagly and Chaiken (1998) define an attitude as "a psychological tendency that is expressed by evaluating a particular entity with some degree of favour or disfavour ( $p .269)$ ". In a technological context, attitudes towards technology could refer to feelings, likes, or dislikes toward technology (Tuncer, 2012; Vega-Gea et al., 2021). The conceptualisation of attitude has not been the same in all previous studies. Different terms can be found in the scientific literature. Each of these terms will be discussed in depth below.

\section{Affective, Cognitive and Behavioural Beliefs}

Authors such as Ostrom (1969) or Norman (1975) consider that attitudes are configured by 3 dimensions: affective, cognitive and behavioral. Affective attitudes refer to "positive or negative" feelings about an issue; cognitive attitudes are based on the beliefs that a person has learned through their life experience; and behavioural attitudes are focused on the behaviour and intention that an individual has when faced with a certain situation where they must act.

If the attitude of teachers is analysed from this prism in relation to gender, different studies did not find statistically significant differences between them (Abdelrahman et al., 2019; Bakr, 2011; Kilinc et al., 2016). These results can be interpreted as a reflection of the democratisation process of equal opportunities in access to technological infrastructure and devices in this century (Albirini, 2006). However, not all studies have corroborated this view, as some have found differences in favour of women (Alodail, 2016; Noori, 2019). According to Alodail (2016), these differential results may be due to teachers finding it difficult to change their habits to initiate themselves into a new, unknown world with a wide range of ICT resources, but that once they begin to become familiar with their use, teachers begin to realise the usefulness that they have in their daily teaching.

\section{Emotional Attitudes}

Authors such as Loyd and Gressard (1984) or Kilinc et al. (2016) have classified attitudes towards technology as emotions or feelings (positive or negative), translated in terms of anxiety, interest or taste. Technological anxiety is defined as a degree of fear or negative emotional state experienced by an individual when using technology (Bozionelos, 2001). However, there are authors who claim that both positions can be closely related, since even if a teacher thinks that technology is a positive thing, they may avoid using it because of anxiety about, contempt for, or inaccessibility of technological devices (Eichenold, 2008). 
If the attitude of teachers between both genders are analysed, from the position of anxiety towards technology, several studies found significant differences (Awofala et al., 2017; Çakir, 2014; Halder \& Chaudhuri, 2011; Papaioannou \& Charalambous, 2011), where female teachers tend to be more nervous than male teachers. Furthermore, Chua et al. (1999), in a meta-analysis of computer anxiety found that females were generally more anxious than males; however, the study was conducted with students rather than teachers, so attitudes among this group may be different. However, not all studies agree with these results. For instance, Semerci and Aydin (2018) analysed anxiety regarding the use of ICT in education with 353 teachers, finding that there were no differences between the both genders.

\section{Self-efficacy Towards Technology}

In the study of attitudes, another variant of the term itself appears to refer to self-efficacy. Alden (1986, $p$. 461) states that, "efficacy concerns an individual's judgment of his or her ability to handle a situation well". In other words, the self-competence that an individual believes they possess to complete a certain task (Bandura, 1977). In technology, this refers to "a judgment of one's capability to use a computer" (Compeau \& Higgins, 1995, p. 192). If beliefs about a person's self-efficacy in performing a task influence their commitment and perseverance in accomplishing it (Ünal et al., 2019), teachers' behavioural beliefs towards technology will significantly influence in the development of their digital competence (Moreira-Fontán et al., 2019).

Some studies suggest that female teachers are often considered less competent in their level of self-efficacy with technological devices (Hammack \& Ivey, 2017; Sieverding \& Koch, 2009). In contrast, a number of studies have found no gender effects (Scherer \& Siddiq, 2015; Shapka \& Ferrari, 2003).

\section{Contribution of This Study}

During the last decades, society has witnessed an accelerated integration of ICTs in all sectors of life. With each new emergence of technological resources, the attitude of individuals toward that new development or technology may vary according to their interests, tastes, emotions, beliefs, or effectiveness. In the educational field, the digital competence of teachers, and specifically their attitude towards technology, has become more important than ever, taking into consideration the health crisis we are experiencing due to COVID-19, considering the acquisition of ICT knowledge relevant for the training of students and, consequently, to train competent graduates to being professionally and effectively adapted to the $21^{\text {st }}$ century labour market. With the importance that ICTs currently have in society, we argue that "either you update yourself digitally or you stay behind the times".

In the context of this research, taking into consideration the meta-analyses on gender differences in attitudes towards technology carried out by Whitley (1997), Liao (1999), and Chua et al. (1999), and given the time that has elapsed not only since the last study of this type (Cai et al., 2017) was conducted in 2017 (furthermore, in this last meta-analysis, the most current manuscript that the author used was from 2014), it is not entirely clear whether the results found are applicable at the beginning of this new decade.

The main difference of the present study with respect to other meta-analyses is that none of the previous ones has focused on analysing the gender differences associated with the technological attitude of a specific group, the teachers who are currently active, since the rest have used samples from different groups (students, future teachers who are not yet practicing, adults, among others). If technology advances by leaps and bounds, who does not claim that the teacher's attitude could also change. Furthermore, some of the moderating variables analysed in this study were not taken into consideration in most of the meta-analyses by these authors, such as the reliability and validity of the measurement instruments; and if they were taken into account, they were not analysed in depth, classifying the variables studied in a series of less exhaustive categories compared to the present study. The differences between the classification of the qualitative categories of the moderating variables analysed in this study and the rest of the meta-analyses are exposed in the discussion of the results, evidencing the contribution of this study. 
Against this background, this study classifies the concept of attitude towards technology into four categories: affect, emotions (anxiety, enjoyment or interest), beliefs (affective, cognitive, and behavioural), and selfefficacy. There are many existing studies in the scientific literature in which the authors have created their own instruments to measure the concept of attitude, but they do not provide a sufficiently clear description of which category the items refer to. Therefore, in view of this situation, this type of study was classified as mixed research, following the advice of Cai et al. (2017).

The research questions addressed in this study are: (a) Are there differences in the attitudes to ICT of working teachers based on gender? (b) Are the effects of gender differences moderated by other variables, including attitudinal typology and methodological characteristics?

In order to answer these questions, the following objectives were set:

- To know if gender is a variable that moderates the effects on the global attitudes towards ICT in teachers (objective 1).

- To identify if there are different effects towards technology by gender according to the different types of attitudes (objective 2).

- To study if variables such as the continent where the study was carried out, the type of institution to which the teacher belongs, the type of publication and psychometric properties of the instruments are moderating variables of the potential relationship between attitudes towards ICT and the teacher's gender (objective 3).

\section{METHOD}

\section{Search Strategy}

The search was carried out in the following databases and web search engines: ScienceDirect, ProQuest Dissertations and Theses, PsycINFO and Google Scholar. For the search, the Boolean operators "and" / "or" were used, both in the title, abstract or keyword sections offered by the different databases. The word strings were as follows:

- Teachers' attitudes towards technology, teachers' attitude towards ICT, teachers' attitude toward computers, teachers' computer anxiety, teachers' technology anxiety, teachers' ICT anxiety, teachers' beliefs technology, teachers' beliefs computer, teachers' beliefs ICT, teacher's self-efficacy towards technology, teacher's self-efficacy towards computer, teacher's self-efficacy towards ICT.

\section{Inclusion and Exclusion Criteria}

The search period was established between January 1, 2000, and July 30, 2020. The inclusion criteria for the meta-analysis were the following:

(a) the work reflected a comparison by gender

(b) the sample used had to be active teachers

(c) information on the sample size was provided

(d) attitudes towards ICT were measured in ex post facto studies, using the mean and standard deviation or the value of the contrast statistic was provided

On the contrary, the exclusion criteria were the following:

(a) the work sample were adults, students, prospective teachers or other types

(b) a comparison was not made based on the gender of the teaching staff 


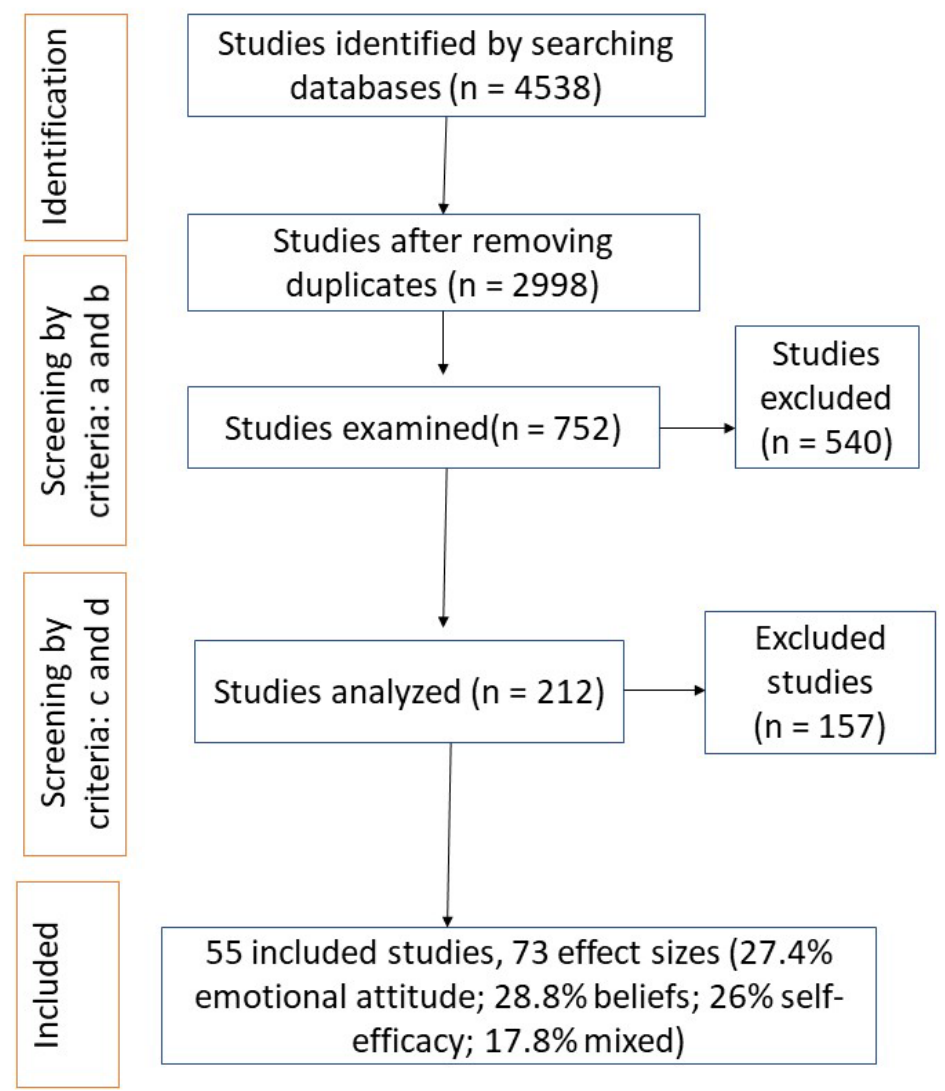

Figure 1. Flowchart of study selection

(c) (f) they were not classified in the different dimensions that make up the attitude construct: emotional affection, beliefs, self-efficacy and mixed

(d) (g) did not present the sample size, nor numerical data or the necessary statistics to calculate the effect size.

The flow chart in Figure 1 details the steps followed, and the sample selected and excluded. These inclusion and exclusion procedures resulted in a sample of 55 studies.

\section{Codification}

In addition to the sample size (number of female and male teachers) and the information used to calculate the effect sizes, the following data were also coded for each study:

- Type of attitude. The attitude measurement domain was coded into four categories, as previously established by Whitley (1997) or Cai et al. (2017) in their meta-analyses: affective-emotional attitude towards ICT, beliefs towards ICT, self-efficacy towards ICT and mixed.

- Continent. The continent where the study was carried out was coded with four levels: America, Africa, Asia and Europe. The rest of the continents were not coded as studies of these places were not selected.

- Decade of publication. This variable was coded with two levels: studies published between 2000 and 2009 and studies published between 2010 and 2020.

- Type of teaching staff. This variable was coded with two categories: early childhood, primary or secondary education teacher and Higher Education teacher.

- Publication format. This variable was coded with 3 levels: articles published in scientific journals, doctoral theses and articles published at conferences. 
Table 1. Magnitude of gender differences in the global attitude towards ICT and in their typologies

\begin{tabular}{|c|c|c|c|c|c|c|c|c|c|}
\hline & \multirow{2}{*}{$\begin{array}{c}\mathrm{N} \\
\text { Male }\end{array}$} & \multirow{2}{*}{$\begin{array}{c}\mathrm{N} \\
\text { Female }\end{array}$} & \multirow{2}{*}{$\begin{array}{c}\mathrm{N} \\
\text { Total }\end{array}$} & \multirow{2}{*}{ k } & \multirow{2}{*}{$d$} & \multicolumn{2}{|c|}{ Confidence interval } & \multicolumn{2}{|c|}{ Heterogeneity } \\
\hline & & & & & & Lower & Upper & $\mathrm{Q}$ & $\mathrm{I}^{2}(\%)$ \\
\hline Emotional & 1850 & 3058 & 4908 & 20 & $-0.342 *$ & -0.524 & -0.160 & $106.744 *$ & 87.18 \\
\hline Beliefs & 1843 & 1682 & 3525 & 21 & $0.114^{*}$ & 0.001 & 0.228 & $45.120^{*}$ & 57.69 \\
\hline Self-Efficacy & 2054 & 2204 & 4258 & 19 & $0.273^{*}$ & 0.118 & 0.4298 & $70.237^{*}$ & 82.17 \\
\hline Mixed & 4014 & 4620 & 8634 & 13 & -0.234 & -1.016 & 0.548 & $1641.07 *$ & 99.64 \\
\hline Total attitude & 9761 & 11564 & 21325 & 73 & -0.022 & -0.189 & 0.145 & $2060.16^{*}$ & 96.91 \\
\hline
\end{tabular}

Note: $\mathrm{k}$ represents the number of effect sizes included. * Statistically significant to 0.05

- Psychometric properties. These characteristics were divided into two variables, reliability and validity, and coded with two categories respectively: studies that provided data on their reliability and studies that did not provide information on their reliability; studies with at least one index on the type of exploratory or confirmatory validity or studies that did not provide any validity index.

\section{Size of the Effect}

To calculate the size of the effect, the Hedges' $\mathrm{g}$ formula with correction for bias (Hedges \& Olkin, 1985) was used, calculated through the difference in means between two samples, and divided by the grouped standard deviation of both:

$$
d=c(g l) \cdot \frac{\bar{X}_{m}-\bar{X}_{f}}{\tilde{S}}
$$

In our case, $\bar{X}_{m}$ is the mean for male teachers, $\bar{X}_{f}$ is the mean for female teachers, $\tilde{S}$ is the grouped standard deviation for both genders, and $c(g)$ represents the degrees of freedom 1- (3/4-gl-1) where $g /$ is $\left(n_{1}-n_{2}-\right.$ 2 ). In those studies that did not provide the standard deviations for each sample, but did offer the contrast statistic $t$, the value of $d$ was deduced. In those studies that did not offer the standard deviations of each sample, but did offer the $t$ test statistic, the value of $d$ was deduced. The interpretation of the effect size is as follows: the positive values for $\mathrm{d}$ reveal that male teachers had a greater attitude towards ICT than female teachers, while negative values show the opposite, that is, female teachers had a higher attitude. The weighted effect sizes were then calculated for each study in order to use them in the analysis of the moderator variables. Specifically, each effect size was weighted by the inverse of its variance (Lee et al., 2016). The analysis of the moderators was based on the random effects model and the homogeneity of the mean effect size was verified with Cochran's Q statistic (DerSimonian \& Laird, 1986). The software used were JAMOVI and Comprehensive Meta-Analysis (CMA) v3.

\section{RESULTS}

\section{Size of the Overall Effect and Variation Between Attitude Typologies}

Table 1 shows the overall effect size for both the attitude construct and its different types. Following Cohen's (2013) classification, the effect size values usually ranged between \pm 3 along with their respective confidence intervals. According to the author, effect sizes of $0.2,0.5$, and 0.8 represent a small, medium, and large effect, respectively. Regarding the overall attitude of teachers, and for the 73 independent effect sizes of this study, a negative effect was found, almost null (not statistically significant, $p>.05$ ), in favour of female teachers, where $d=-0.022$ with a $95 \%$ confidence interval of -0.189 to 0.145 .

To better understand the overall effect sizes found, we could compare these results with the findings of previous studies related to the topic. For example, in the meta-analyses by Cai et al. (2017), Liao (1999) Whitley (1997) small and medium overall effect sizes were found, all significant, in attitudes towards technology in favour of male individuals $(d=0.17 ; d=0.19 ; d=0.232)$, respectively, and all significant. As previously commented, such differences in attitudes towards technology with respect to gender may have been due to the type of sample used. For example, Cai et al. (2017) used students, teachers, employees, and web users, in their study; while Whitley (1997) and Liao (1999) used adults, university students, high school 
students, primary school students, or a mixed population. Compared to the current study, which used only active teachers, no differences were found in overall attitudes towards educational use of ICT, corroborating the findings of Abdelrahman et al. (2019), Bakr (2011), Kilinc et al. (2016), and Zyad (2016). The explanation for not finding significant differences between both genders could be twofold: on the one hand, the democratisation process currently underway in terms of equal opportunities (Albirini, 2006), and, on the other, and easy access to digital content (Alvarado et al., 2020).

If each dimension of the attitude construct is analysed separately, because the conceptualisation of the term has been studied using different approaches, three significant effect sizes are found, for the emotional dimensions, and self-efficacy. For the emotional attitude dimension, a small to medium effect size was found $(d=-0.342, p<.05)$, in favour of female teachers (with higher scores for female teachers), while for the other two dimensions, males showed a more positive and favourable attitude in terms of direction (beliefs: $d=$ $0.144, p<.05$; self-efficacy: $d=0.273, p<.05$ ).

To check whether the effect sizes estimated the same population parameter, a heterogeneity test was performed on those dimensions that had a significant effect size (emotional, beliefs, and self-efficacy). The $Q$ statistic showed variability and significance in the analysed studies, rejecting the hypothesis of homogeneity. The values obtained were the following: attitude emotional $Q=106.744, p<.05$, beliefs $Q=$ 45.120, $p<.05$, and self-efficacy $Q=70.237, p<.05$. These values of $Q$ indicate the existence of real differences in the effect sizes between samples (heterogeneity), reaffirming that this was due to the diverse nature of the studies, which indicates the need to carry out an analysis of moderating variables that can explain this variability in effect sizes.

The $Q$ statistic informs us about the existence or not of significant heterogeneity, but not about the degree of such heterogeneity. Therefore, we calculated the $\mathrm{I}^{2}$ index (Higgins et al., 2003), which informs us about the degree of true heterogeneity of the effect sizes. Coefficients of around $25 \%, 50 \%$, and $75 \%$, can be interpreted as low, moderate, and high heterogeneity, respectively. Therefore, the values of the $\mathrm{I}^{2}$ statistic suggested that between $57 \%$ and $87 \%$ of the variability in each of the dimensions analysed could be attributed to true heterogeneity rather than random error (emotional, $I^{2}=87.18 \%$; beliefs, $I^{2}=57.69 \%$; selfefficacy, $I^{2}=82.17$ ). For this reason, an analysis of moderating variables was performed following the random effects model.

If we compare the findings of this study with previous studies, a certain similarity but also a discrepancy can be observed, depending on the dimension analysed, in terms of direction. With regard to emotional attitudes related to anxiety, fun or enjoyment of the use of technology, authors such as Whitley (1997), and Cai et al. (2017) found significant and positive effect sizes ( $d=0.259$ and $d=0.100$, respectively) in favour of the male sex, which would go against those obtained in our study, where we have found a higher score in female teachers. These results may be associated with multiple factors: on the one hand, the percentage of studies included in the current meta-analysis focusing on anxiety towards technology with respect to the total number of studies of this dimension (70\%), corroborating the results of Awofala et al. (2017), Çakir (2014), Halder and Chaudhuri (2011), and Papaioannou and Charalambous (2011), and who found that female teachers tend to be more nervous when working with technological devices or resources. That is, if one takes into consideration that most studies measure anxiety and that the female sex has obtained a higher score compared to the male sex, it could be interpreted that the favourable activity is for the male sex. And, on the other hand, the methodological design of the studies included in these authors' meta-analyses, as this attitude construct analyses different types of emotions that can be interpreted as positive or negative attitudes (anxiety or fun), meaning that, depending on what the authors measured, the size of the effect could move in one direction or another.

Regarding beliefs, studies such as those by Liao (1999), and Whitley (1997) found a very small effect $(d=$ 0.020 and $d=0.065$, respectively), while Cai et al. (2017) found a small effect $(d=0.27)$. These results corroborate the coefficients found in this study, both in the value of the effect size, being small, and in the direction of the effect, being a positive effect. It could therefore be said that all these studies agree that the male sex tends to have more favourable beliefs regarding the use of technology than the female sex. These 
results are consistent with the statements by Alodail (2016) that, although a priori there may be differences in attitudes towards technology, once teachers have the initiative to become involved in the world of technology, the discrepancies in levels with regard to gender decrease, with very small significant differences being found. Regardless of the differences in ex, it must be taken into consideration that, in this type of construct, as Ajzen (2005) states, beliefs refer to negative or positive perceptions of an issue, so the combination of both elements could dilute the gender difference. For example, the study by Bakr (2011) found one negative effect $(d=-0.42)$ for the affective dimension and two positive effects for the cognitive and behavioural dimensions $(d=0.12 ; d=0.07)$. Therefore, in future works, the study of beliefs towards technology should provide both positive and negative items separately, as well as affective, cognitive, and behavioural categories, corroborating Whitley's (1997) conclusions.

With regard to self-efficacy, the effect found in this meta-analysis $(d=0.273)$ is greater than the effect identified by Cai et al. (2017; $d=0.18$ ) and less than the effect found by Whitley $(1997 ; d=0.41)$. However, in all three studies, both the size of the effect (small effects), and in the direction of it (self-efficacy towards the higher technology in male teachers) are similar, corroborating the results of other studies (Hammack \& Ivey, 2017; Sieverding \& Koch, 2009). In view of these findings, we agree with the contributions of Ünal et al. (2019) when they state that self-efficacy is a key element in the development of digital teaching competence, closely linked to self-efficacy and behavioural beliefs in regard to the use of technology. Therefore, it must be a priority objective to achieve the commitment and perseverance of teachers in the use of technology, mainly among the female ex, and, in this way, to reduce the existing digital divide.

Table 2 shows the individual effect size for each study included in the meta-analysis.

Table 2. Individual studies included in the meta-analysis

\begin{tabular}{|c|c|c|c|c|c|c|c|c|c|c|}
\hline \multirow{2}{*}{ Study } & \multicolumn{2}{|c|}{ Sample } & \multirow{2}{*}{\multicolumn{2}{|c|}{ Attitude Continent }} & \multirow{2}{*}{ Place of work } & \multirow{2}{*}{ Publication } & \multirow{2}{*}{$\mathrm{R}$} & \multirow{2}{*}{ V } & \multirow{2}{*}{$d$} & \multirow{2}{*}{ Std Err } \\
\hline & $\mathrm{M}$ & $\mathrm{F}$ & & & & & & & & \\
\hline Abdelrahman et al. (2019) & 179 & 41 & B & Asia & University & Journal & Yes & No & -0.29 & 0.173 \\
\hline Ahmad (2000) & 55 & 193 & $E$ & USA & Prim. / Sec. & Thesis & No & No & 0.16 & 0.153 \\
\hline Ahmad (2000) & 55 & 193 & $E$ & USA & Prim. / Sec. & Thesis & No & No & 0.14 & 0.153 \\
\hline Al-Ghazo (2008) & 142 & 19 & B & USA & University & Thesis & Yes & No & 0.07 & 0.243 \\
\hline Alqahtani (2019) & 68 & 40 & SE & USA & Primary & Thesis & Yes & No & 0.22 & 0.198 \\
\hline Alrasheedi (2009) & 82 & 85 & B & USA & Secondary & Thesis & Yes & Yes & 0.37 & 0.155 \\
\hline Alzamil (2003) & 99 & 84 & B & USA & Secondary & Thesis & Yes & No & -0.04 & 0.148 \\
\hline Alzidiyeen et al. (2011) & 242 & 223 & $E$ & USA & Primary & Journal & Yes & No & -0.34 & 0.093 \\
\hline Alzidiyeen et al. (2011) & 242 & 223 & SE & USA & Primary & Journal & Yes & No & 0.29 & 0.093 \\
\hline Akcay et al. (2015) & 189 & 71 & M & Asia & University & Journal & Yes & No & 0.75 & 0.143 \\
\hline Annaraja \& Joseph (2006) & 13 & 18 & $\mathrm{E}$ & Asia & University & Journal & No & No & -0.44 & 0.359 \\
\hline Arques (2013) & 104 & 106 & M & Europe & Prim. / Sec. & Thesis & Yes & Yes & 0.18 & 0.138 \\
\hline Bakr (2011) & 53 & 65 & $\mathrm{~B}$ & Africa & Secondary & Journal & No & No & -0.42 & 0.186 \\
\hline Bakr (2011) & 53 & 65 & B & Africa & Secondary & Journal & No & No & 0.12 & 0.184 \\
\hline Bakr (2011) & 53 & 65 & $\mathrm{~B}$ & Africa & Secondary & Journal & No & No & 0.07 & 0.184 \\
\hline Bas \& Senturk (2018) & 93 & 107 & SE & Asia & Prim. / Sec. & Journal & No & No & 0.08 & 0.141 \\
\hline Bektas (2016) & 85 & 86 & SE & Asia & Child. / Prim. & Congress & Yes & Yes & 0.31 & 0.153 \\
\hline Birgin et al. (2020) & 121 & 121 & SE & Asia & Prim. / Sec. & Journal & Yes & Yes & 0.08 & 0.128 \\
\hline Burke (2014) & 40 & 157 & SE & USA & Child. / Prim./ Sec. & Thesis & Yes & No & 0.38 & 0.177 \\
\hline Çakir (2014) & 287 & 481 & $E$ & Asia & Child & Journal & Yes & Yes & -0.53 & 0.076 \\
\hline Çakir (2014) & 287 & 481 & $E$ & Asia & Child & Journal & Yes & Yes & -0.58 & 0.076 \\
\hline Cavas et al. (2009) & 507 & 664 & $M$ & Asia & Primary & Journal & Yes & No & -0.07 & 0.059 \\
\hline Chou (2003) & 71 & 65 & $E$ & Asia & Secondary & Journal & Yes & Yes & -0.94 & 0.180 \\
\hline Deniz (2007) & 19 & 71 & $E$ & Asia & University & Journal & Yes & No & -0.03 & 0.256 \\
\hline Deniz (2007) & 19 & 71 & $E$ & Asia & University & Journal & Yes & No & -0.52 & 0.259 \\
\hline Denson (2005) & 34 & 114 & B & USA & Secondary & Thesis & Yes & No & -0.06 & 0.194 \\
\hline Embi (2007) & 76 & 186 & $E$ & USA & University & Thesis & Yes & No & -0.03 & 0.136 \\
\hline Embi (2007) & 76 & 186 & SE & USA & University & Thesis & Yes & No & 0.14 & 0.136 \\
\hline
\end{tabular}

Note: Sample= Male (M), Female (F). Type of attitude = Emotional (E), Beliefs (B), Self-efficacy (SE), Mixed (M). Place of work= Child (Early Childhood Education), Prim. (Primary), Sec (Secondary). Reliability (R). Validity (V). Effect size (d) 
Table 2 (continued). Individual studies included in the meta-analysis

\begin{tabular}{|c|c|c|c|c|c|c|c|c|c|c|}
\hline \multirow{2}{*}{ Study } & \multicolumn{2}{|c|}{ Sample } & \multirow{2}{*}{\multicolumn{2}{|c|}{ Attitude Continent }} & \multirow{2}{*}{ Place of work } & \multirow{2}{*}{ Publication } & \multirow{2}{*}{$\mathrm{R}$} & \multirow{2}{*}{ V } & \multirow{2}{*}{$d$} & \multirow{2}{*}{ Std Err } \\
\hline & $\mathrm{M}$ & $\mathrm{F}$ & & & & & & & & \\
\hline Fernández \& Bermejo (2012) & 25 & 38 & $\mathrm{~B}$ & Europe & Secondary & Journal & Yes & Yes & 0.54 & 0.259 \\
\hline González et al. (2017) & 444 & 778 & M & Europe & Prim. / Sec. & Journal & No & No & -3.46 & 0.092 \\
\hline Halder \& Chaudhuri (2011) & 43 & 41 & $E$ & Asia & Secondary & Congress & No & No & -1.21 & 0.256 \\
\hline Halder \& Chaudhuri (2011) & 43 & 41 & SE & Asia & Secondary & Congress & No & No & 1.78 & 0.236 \\
\hline Helms (2004) & 9 & 32 & SE & USA & Prim. / Sec. & Thesis & Yes & No & 0.45 & 0.373 \\
\hline Hong \& Koh (2002) & 112 & 88 & $E$ & Asia & Secondary & Journal & Yes & Yes & -0.41 & 0.143 \\
\hline Hong \& Koh (2002) & 112 & 88 & $\mathrm{~B}$ & Asia & Secondary & Journal & Yes & Yes & 0.26 & 0.143 \\
\hline Islahi (2019) & 245 & 237 & $M$ & Asia & Secondary & Journal & Yes & No & 0.15 & 0.091 \\
\hline Jegede (2007) & 146 & 72 & SE & Africa & Secondary & Journal & No & No & -0.03 & 0.144 \\
\hline Johnson (2001) & 64 & 67 & M & USA & University & Thesis & No & No & -0.39 & 0.175 \\
\hline Kabataş \& Karaoğlan (2018) & 111 & 101 & SE & Asia & Mixed & Journal & No & No & -0.25 & 0.138 \\
\hline Kagima \& Hausafus (2000) & 111 & 65 & SE & USA & University & Journal & Yes & No & 0.34 & 0.157 \\
\hline Kahraman \& Yilmaz (2018) & 143 & 206 & SE & Asia & Mixed & Journal & Yes & Yes & 0.01 & 0.109 \\
\hline Kemp (2002) & 252 & 173 & $\mathrm{~B}$ & USA & Secondary & Thesis & No & No & 0.23 & 0.099 \\
\hline Kemp (2002) & 252 & 173 & SE & USA & Secondary & Thesis & No & No & 0.22 & 0.099 \\
\hline Kiliç (2015) & 48 & 76 & $E$ & Asia & Prim. / Sec. & Journal & Yes & No & -0.76 & 0.189 \\
\hline Kiliç (2015) & 48 & 76 & SE & Asia & Prim. / Sec. & Journal & Yes & No & 0.70 & 0.189 \\
\hline Kilinc et al. (2016) & 67 & 78 & $\mathrm{~B}$ & Asia & Secondary & Journal & Yes & No & -0.16 & 0.166 \\
\hline Kilinc et al. (2016) & 67 & 78 & $E$ & Asia & Secondary & Journal & Yes & No & -0.14 & 0.166 \\
\hline Kpolovie \& Awusaku (2016) & 251 & 149 & B & Africa & University & Journal & Yes & Yes & 0.17 & 0.103 \\
\hline Kretschmann (2015) & 26 & 31 & B & USA & Secondary & Journal & No & No & -0.16 & 0.263 \\
\hline Lin et al. (2013) & 94 & 130 & SE & Asia & Secondary & Journal & Yes & Yes & 0.46 & 0.137 \\
\hline Noori (2019) & 27 & 26 & $\mathrm{~B}$ & Asia & University & Journal & Yes & No & 0.45 & 0.274 \\
\hline Olafare et al. (2018) & 38 & 85 & $M$ & Asia & University & Journal & No & No & -0.07 & 0.060 \\
\hline Olafare et al. (2020) & 123 & 130 & $M$ & Africa & Secondary & Journal & Yes & No & -0.06 & 0.125 \\
\hline Olanrewaju et al. (2020) & 97 & 21 & $M$ & Africa & University & Journal & Yes & No & 2.24 & 0.280 \\
\hline Onasanya et al. (2010) & 90 & 60 & $M$ & Africa & University & Journal & Yes & No & -2.83 & 0.233 \\
\hline Öztürk (2018) & 88 & 80 & $E$ & Asia & Primary & Journal & Yes & Yes & -0.39 & 0.155 \\
\hline Pavlou \& Vryonides (2009) & 157 & 293 & M & Europe & Prim. / Sec. & Journal & Yes & Yes & 0.35 & 0.099 \\
\hline Sarfo et al. (20017) & 229 & 178 & SE & Africa & University & Journal & Yes & No & 0.26 & 0.100 \\
\hline Semerci \& Aydin (2018) & 150 & 203 & B & Asia & University & Journal & Yes & No & -0.04 & 0.107 \\
\hline Semerci \& Aydin (2018) & 150 & 203 & $E$ & Asia & University & Journal & Yes & No & -0.15 & 0.108 \\
\hline Simsek (2011) & 38 & 85 & $E$ & Asia & Prim. / Sec. & Journal & Yes & No & -0.51 & 0.194 \\
\hline Simsek (2011) & 38 & 85 & SE & Asia & Prim. / Sec. & Journal & Yes & No & 0.06 & 0.197 \\
\hline Tezci (2010) & 696 & 844 & M & Asia & Primary & Journal & Yes & Yes & 0.03 & 0.051 \\
\hline Tezci (2010) & 696 & 844 & $M$ & Asia & Primary & Journal & Yes & Yes & 0.16 & 0.051 \\
\hline Tweed (2013) & 80 & 44 & SE & USA & Child /Prim. & Thesis & No & No & 0.28 & 0.187 \\
\hline Valdés-Cuervo et al. (2011) & 56 & 92 & $\mathrm{~B}$ & Europe & Primary & Journal & Yes & Yes & 0.48 & 0.171 \\
\hline Velasquez (2002) & 83 & 197 & B & USA & Prim. / Sec. & Thesis & Yes & No & -0.02 & 0.131 \\
\hline Williams (2006) & 25 & 154 & $E$ & USA & Primary & Thesis & No & No & 0.72 & 0.218 \\
\hline Williams (2006) & 25 & 154 & $E$ & USA & Primary & Thesis & No & No & -0.81 & 0.219 \\
\hline Yehya et al. (2019) & 105 & 36 & $E$ & Asia & Secondary & Journal & No & No & -0.18 & 0.192 \\
\hline Zyad (2016) & 33 & 23 & B & Africa & Secondary & Journal & No & No & 0.02 & 0.268 \\
\hline Zyad (2016) & 33 & 23 & B & Africa & Secondary & Journal & No & No & 0.89 & 0.281 \\
\hline Zyad (2016) & 33 & 23 & $\mathrm{~B}$ & Africa & Secondary & Journal & No & No & 0.44 & 0.271 \\
\hline
\end{tabular}

Note: Sample $=$ Male $(M)$, Female (F). Type of attitude $=$ Emotional $(E)$, Beliefs (B), Self-efficacy (SE), Mixed (M). Place of work= Child (Early Childhood Education), Prim. (Primary), Sec (Secondary). Reliability (R). Validity (V). Effect size (d)

\section{Analysis of Moderators}

Table 3 presents the categorical moderator analyses, following the mixed effects model, of the following variables: continent, teacher's workplace, decade in which the studies are published, type of publication, and psychometric properties, both for the global attitude and for its typologies (those in which significant effect sizes were found: emotional, beliefs and self-efficacy - see Table 1). 
Table 3. Moderator analysis for variation in gender differences in attitude towards ICT

\begin{tabular}{|c|c|c|c|c|c|c|c|c|c|}
\hline & \multicolumn{3}{|c|}{ Emotional } & \multicolumn{3}{|c|}{ Beliefs } & \multicolumn{3}{|c|}{ Self-Efficacy } \\
\hline & k & d & $\mathrm{Cl} 95 \%$ & $\mathrm{k}$ & d & $\mathrm{Cl} 95 \%$ & k & $\mathrm{d}$ & Cl $95 \%$ \\
\hline \multicolumn{10}{|l|}{ Continent } \\
\hline Asia & 14 & $-0.48^{*}$ & $(-0.62,-0.33)$ & 5 & 0.01 & $(-0.21,0.24)$ & 9 & $0.32 *$ & $(0.04,0.60)$ \\
\hline Africa & & & & 7 & 0.15 & $(-0.12,0.42)$ & 2 & 0.13 & $(-0.15,0.42)$ \\
\hline USA & 6 & -0.03 & $(-0.36,0.30)$ & 7 & 0.09 & $(-0.10,0.23)$ & 8 & $0.26^{*}$ & $(0.17,0.36)$ \\
\hline Europe & & & & 2 & $0.50 *$ & $(0.22,0.78)$ & & & \\
\hline $\mathrm{Q}_{\mathrm{B}}$ & \multicolumn{3}{|c|}{$(5.95)^{*}$} & \multicolumn{3}{|c|}{$(7.98)^{*}$} & \multicolumn{3}{|c|}{$(0.97)$} \\
\hline \multicolumn{10}{|l|}{ Work } \\
\hline School & 15 & $-0.38^{*}$ & $(-0.57,-0.20)$ & 16 & $0.14^{*}$ & $(0.01,0.28)$ & 15 & $0.30 *$ & $(0.13,0.47)$ \\
\hline University & 5 & $-0.15^{*}$ & $(-0.30,-0.01)$ & 5 & 0.04 & $(-0.16,0.24)$ & 3 & $0.24 *$ & $(0.10,0.38)$ \\
\hline$Q_{B}$ & \multicolumn{3}{|c|}{ (3.72) } & \multicolumn{3}{|c|}{$(0.68)$} & \multicolumn{3}{|c|}{$(4.51)^{*}$} \\
\hline \multicolumn{10}{|l|}{ Decade } \\
\hline 2000-2009 & 10 & -0.21 & $(-0.51,0.09)$ & 7 & $0.14^{*}$ & $(0.01,0.26)$ & 5 & $0.18^{*}$ & $(0.06,0.31)$ \\
\hline 2010-2020 & 10 & $-0.45^{*}$ & $(-0.60,-0.30)$ & 14 & 0.12 & $(-0.05,0.28)$ & 14 & $0.30 *$ & $(0.13,0.47)$ \\
\hline $\mathrm{Q}_{\mathrm{B}}$ & \multicolumn{3}{|c|}{$(2.06)$} & \multicolumn{3}{|c|}{$(0.85)$} & \multicolumn{3}{|c|}{$(1.13)$} \\
\hline \multicolumn{10}{|l|}{ Publication } \\
\hline Journal & 14 & $-0.43^{*}$ & $(-0.55,-0.31)$ & 15 & 0.13 & $(-0.03,0.28)$ & 11 & $0.17^{*}$ & $(0.04,0.31)$ \\
\hline Conferences & 1 & $-1.21^{*}$ & $(-1.67,-0.75)$ & & & & 2 & 1.03 & $(-0.40,2.46)$ \\
\hline Thesis & 5 & 0.04 & $(-0.34,0.42)$ & 6 & 0.11 & $(-0.03,0.25)$ & 6 & $0.24 *$ & $(0.12,0.36)$ \\
\hline $\mathrm{Q}_{\mathrm{B}}$ & \multicolumn{3}{|c|}{$(16.83)^{*}$} & \multicolumn{3}{|c|}{$(0.89)$} & \multicolumn{3}{|c|}{$(1.75)$} \\
\hline \multicolumn{10}{|l|}{ Reliability } \\
\hline No & 7 & -0.22 & $(-0.67,0.23)$ & 8 & 0.13 & $(-0.11,0.36)$ & 6 & 0.30 & $(-0.08,0.68)$ \\
\hline Yes & 13 & $-0.41^{*}$ & $(-0.54,-0.28)$ & 13 & 0.11 & $(-0.02,0.24)$ & 13 & $0.26 *$ & $(0.16,0.35)$ \\
\hline $\mathrm{Q}_{B}$ & \multicolumn{3}{|c|}{$(0.65)$} & \multicolumn{3}{|c|}{$(0.02)$} & \multicolumn{3}{|c|}{$(0.05)$} \\
\hline \multicolumn{10}{|l|}{ Validity } \\
\hline No & 15 & $-0.26^{*}$ & $(-0.46,-0.06)$ & 16 & 0.03 & $(-0.09,0.16)$ & 15 & $0.29 *$ & $(0.12,0.49)$ \\
\hline Yes & 5 & $-0.55^{*}$ & $(-0.68,-0.42)$ & 5 & $0.29 *$ & $(0.17,0.42)$ & 4 & 0.21 & $(-0.01,0.42)$ \\
\hline $\mathrm{Q}_{\mathrm{B}}$ & \multicolumn{3}{|c|}{$(5.99)^{*}$} & \multicolumn{3}{|c|}{$(8.10)^{*}$} & \multicolumn{3}{|c|}{$(0.35)$} \\
\hline
\end{tabular}

Note. $\mathrm{k}=$ number of studied being included, $\mathrm{d}=$ effect size, $\mathrm{Cl} 95 \%$ = Wald's confidence interval $95 \%, \mathrm{Q}_{B}=$ inter-category homogeneity

With regard to the first characteristic (continent), the statistic $Q_{B}$ indicated that the average effect sizes between some continents varied when significant differences were found. Specifically, in the emotional $\left(Q_{B}\right.$ $(2)=5.95 ; p<.05)$ and belief $\left(Q_{B}(4)=7.98 ; p<.05\right)$ dimensions it was observed that the continent variable explained part of the variability in the effect sizes, where gender differences were higher in samples from Asia (emotional dimension, $d=-0.48$ ) and in samples from Europe (beliefs dimension, $d=-0.50$ ). These differences between continents may be due to the fact that the curricular integration of technology is not carried out in the same way, depending on the social and cultural phenomena of each continent (Davies, 2004). The results found are corroborated in part by Cai et al. (2017) since the authors not only found significant differences in the emotional dimensions and beliefs, but also in the self-efficacy dimension, as well as in the global attitude. If the results are compared with those of Liao (1999), the findings are contradictory since they did not find significant differences according to the place of origin. Perhaps a possible explanation is due to the fact that this author only divided the sample into participants from and not from the United States. Finally, it is not possible to compare the results with those of the meta-analysis by Whitley (1997) since this variable was not analysed.

The moderating variable workplace of teachers does not seem to affect the variability in gender differences of the effect sizes analysed in the emotional and beliefs dimensions, except in the self-efficacy dimension $\left(Q_{B}\right.$ $(2)=4.51 ; p<.05)$. The results found are contradictory to those reached by Cai et al. (2017) which did find significant differences in the emotional dimensions and beliefs and not in the self-efficacy dimension. If the results are compared with Whitley (1997), we find similarity in the results for the belief and self-efficacy dimensions and contradictory for the emotional dimension. Between both authors, the results of this study are closer to those found by Whitley (1997) with respect to those of Cai et al. (2017). Perhaps a possible explanation for these findings is due to the fact that these authors used different types of samples, including 
students, teachers or others, while in our study we only included active teachers, so the validity of our results is more extrapolated to the population under study. Finally, it is not possible to compare the results with those of Liao (1999) since this variable was not analyzed.

With regard to the results found regarding the moderator 'decade', these are in line with the results of Cai et al. (2017), Liao (1999), and Whitley (1997), who analysed the correlation between the attitude towards technology and the date of publication, not finding a significant relationship. The difference in and contribution of our study is the further classification of the studies, both by decade and typology of attitude, while the other two studies only performed analysis at a global level.

It was tested whether the magnitude of gender differences in attitudes towards ICT varied according to the type of publication. There is evidence that supports significant differences between publication types, in the emotional $\left(\mathrm{Q}_{\mathrm{B}}(3)=16.83 ; p<.05\right)$. The effect sizes in the emotional dimension varied from -1.21 (conferences) to 0.04 (thesis). These results are contradictory to those of Liao (1999) and are partially corroborated with the findings of Cai et al. (2017) when finding that the moderating variable type of publication explained part of the variability of the gender differences in the effect sizes of the emotional dimension, but contradictory with the self-efficacy dimension since the author did find significant differences. The main contribution of this study with respect to the other meta-analyses is that Whitley (1997) did not analyse this moderating variable and Cai et al. (2017) only distinguished between journal articles and doctoral theses, while this study also includes articles published at conferences.

With respect to the psychometric properties of the studies (reliability and validity), according to our results, the moderating variable reliability does not affect the variability in effect sizes, there being no differences between those studies that do provide these methodological characteristics and the studies that do not provide this information, corroborating the results of Liao (1999). However, significant differences were found in the validity variable in the emotional dimension $\left(Q_{B}(2)=5.99 ; p<.05\right)$ and beliefs dimension $\left(Q_{B}(2)\right.$ $=8.10 ; p<.05)$. For example, it is observed that the largest effect size in the validity variable is found in those studies that did carry out and included this type of psychometric properties compared to those that did not provide this evidence. These results are relevant since the other meta-analyses did not carry out this type of analysis.

The results obtained suggest that the territory where the integration of ICT was carried out, the teacher's workplace, type of publication, as well as the validity of the instruments can explain part of the differences in the attitude of teachers towards technology linked gender, in some of the dimensions analysed. One possible explanation for the significance of the territory was provided by Collis (1999), Davies (2004), and Li and Kirkup (2007), as discussed above; however, one must ask: why in the initial stages is there a greater difference in attitudes towards technology regarding the effectiveness that teachers believe they have? Is it because there is a gradual relationship in the level of attitude depending on whether the teacher is in initial or higher stages? Are studies with greater scientific rigor carried out according to the type of publication? Does the peer review carried out by journal, congress or doctoral thesis supervisors affect the design of the research, and consequently, the gender differences? Why are significant differences found when the validity of the instrument is checked, but not when the reliability is checked? This type of question requires a greater depth in this type of study.

\section{CONCLUSIONS}

In this meta-analysis, we have provided further evidence of gender differences in teachers' attitudes to ICT, and different moderators have been shown to play a significant role in the variability of effect sizes. The results of this meta-analysis indicate that, in general, there are no significant gender differences; however, some differences in the emotional, beliefs, and self-efficacy dimensions of attitude were found. The significant differences between the effect sizes in each of the dimensions analysed are quite interesting, and more researches are needed to address the objective of this study, as the direction of the attitude towards gender may vary depending on how the studies have been designed, and what type of attitude is measured. 
The results found may have several implications at the educational and research level, from the perspective of the educational institution, in order to focus on training actions in those constructs and gender that present less favourable attitudes towards the use of educational technology, to the methodological perspective, on the importance of well-designed studies with complete sampling procedures and psychometric quality.

Furthermore, our study provides some evidence that the moderators continent, workplace, type of publication and instrument validity can produce inequalities in the effect sizes of gender differences. Nonetheless, it remains unknown what other factors can contribute to explaining the variability of significant effects. In addition, it should be pointed out that there are certain limitations to this meta-analysis, as there are few studies from different continents - in particular there is a lack of studies in Oceania - and studies published in different media, such as congresses. This information is useful in itself.

In conclusion, the study of the attitudes towards ICT of active teachers will allow innovative teachers and scientific researchers to continue designing training programs that contribute not only to their acquisition and development in teachers, but also to their own integration into the teaching profession. teachinglearning processes, with the purpose of being able to provide a higher quality education. With this metaanalysis, it is possible to take an important step towards a better measurement and understanding of the attitudes towards ICT of active teachers, according to gender.

Author contributions: All authors were involved in concept, design, collection of data, interpretation, writing, and critically revising the article. All authors approve final version of the article.

Funding: The authors received no financial support for the research and/or authorship of this article.

Declaration of interest: Authors declare no competing interest.

Research involving human participants and/or animals: Authors declare that the study has not been carried out with human or animal participants.

Informed consent: Authors declare that they have not used human samples, so they have not had to request consent.

Data availability: Data generated or analysed during this study are available from the authors on request.

\section{REFERENCES}

Abdelrahman, M. A., Abdelraheem, A. Y., Al-Shedani, Z. A., \& Al Aghbari, M. S. (2019). An investigation of faculty members' beliefs and barriers to successful ICT integration into teaching at Sultan Qaboos University. i-Manager's Journal of Educational Technology, 16(2), 50-61. https://doi.org/10.26634/jet.16.2.16240

Ahmad, A. M. H. (2000). An investigation of attitudes of inservice teachers towards computer technology use in schools in a southwest border district (Doctoral dissertation, New Mexico State University).

Ajzen, I. (2005). Attitudes, personality, and behavior. McGraw-Hill Education.

Akcay, A., Halit, A., \& Ufuk, G. (2015). Teachers' attitudes toward using interactive white boards. Middle Eastern \& African Journal of Educational Research, 17, 22-30.

Albirini, A. (2006). Teachers' attitudes toward information and communication technologies: The case of

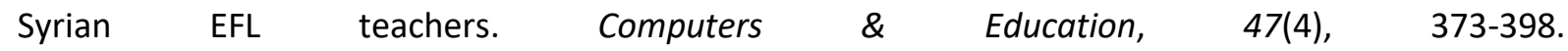
https://doi.org/10.1016/j.compedu.2004.10.013

Alden, L. (1986). Self-efficacy and causal attributions for social feedback. Journal of Research in Personality, 20(4), 460-473. https://doi.org/10.1016/0092-6566(86)90126-1

Al-Ghazo, A. (2008). Technology integration in university teachers' education programs in Jordan: Comparisons of competencies, attitudes and perceptions toward integrating technology in the classroom (Order No. 3310999). Dissertations \& Theses Global, Southern Illinois University Carbondale

Alodail, A. (2016). The instructors' attitudes toward the use of e-learning in classroom in College of Education at Albaha University. Turkish Online Journal of Educational Technology-TOJET, 15(1), 126-135. 
Alqahtani, M. M. (2019). Self-efficacy and Factors Affecting the Levels of Technology Implementation among Teachers in Saudi Arabia (Doctoral dissertation, Indiana State University).

Alrasheedi, H. S. (2009). Information and communication technology (ICT): Effects of gender and training among Kuwait teachers (Doctoral dissertation, Ohio University).

Alvarado, L. E., Aragón, R. R., \& Bretones, F. D. (2020). Teachers' attitudes towards the introduction of ICT in Ecuadorian public schools. TechTrends, 1-8. https://doi.org/10.1007/s11528-020-00483-7

Alzamil, O. (2003). High school social studies teachers' attitudes and usage of instructional technology in Saudi Arabia (Unpublished doctoral thesis, Faculty of Education, University of Arkansas, the USA).

Alzidiyeen, N. J., Abdullah, A. G. K., Seedee, R., \& Al-Shabatat, A. M. (2011). Gender and age differences in computer usage, competence, attitudes, self-efficacy, and anxiety among teachers in Jordan. Elixir International Journal, 37, 3782-3789.

Annaraja, P., \& Joseph, N. M. (2006). Teacher trainees' attitude towards information and communication technology. DESIDOC Journal of Library \& Information Technology, 26(2), 37-40. https://doi.org/10.14429/dbit.26.2.3678

Arques Rosas, R. (2013). Las actitudes del profesorado de música ante las Tecnologías de la Información y la Comunicación [The attitudes of music teachers towards Information and Communication Technologies] (Doctoral thesis, Education Faculty, University of Alicante, Spain).

Awofala, A. O., Akinoso, S. O., \& Fatade, A. O. (2017). Attitudes towards computer and computer self-efficacy as predictors of preservice mathematics teachers' computer anxiety. Acta Didactica Napocensia, 10(3), 91-108. https://doi.org/10.24193/adn.10.3.9

Azmi, N. J., Hassan, I., Ab Rashid, R., Ahmad, Z., Aziz, N. A., \& Nasidi, Q. Y. (2021). Gender Stereotype in Toy Advertisements on Social Networking Sites. Online Journal of Communication and Media Technologies, 11(4), e202122. https://doi.org/10.30935/ojcmt/11212

Bakr, S. M. (2011). Attitudes of Egyptian teachers towards computers. Contemporary Educational Technology, 2(4), 308-318. https://doi.org/10.30935/cedtech/6061

Bandura, A. (1977). Self-efficacy: toward a unifying theory of behavioral change. Psychological Review, 84(2), 191-215. https://doi.org/10.1037/0033-295X.84.2.191

Bas, G., \& Senturk, C. (2018). An evaluation of Technological Pedagogical Content Knowledge (TPACK) of inservice teachers: A study in Turkish public schools. International Journal of Educational Technology, $5(2), 46-58$.

Bektas, M. (2016). The perceived self-efficacy of classroom teachers and preschool teachers for teaching with tablets. In SHS Web of Conferences (Vol. 26, p. 01091). EDP Sciences. https://doi.org/10.1051/shsconf/20162601091

Birgin, O., Uzun, K., \& Akar, S. G. M. (2020). Investigation of Turkish mathematics teachers' proficiency perceptions in using information and communication technologies in teaching. Education and Information Technologies, 25(1), 487-507. https://doi.org/10.1007/s10639-019-09977-1

Bozionelos, N. (2001). The relationship of instrumental and expressive traits with computer anxiety. Personality and Individual Differences, 31(6), 955-974. https://doi.org/10.1016/S0191-8869(00)001987

Burke, L. F. (2014). Teachers' perceived self-efficacy in integrating technology into pedagogical practice and barriers to technology integration (Doctoral dissertation, Johnson \& Wales University).

Cai, Z., Fan, X., \& Du, J. (2017). Gender and attitudes toward technology use: A meta-analysis. Computers \& Education, 105, 1-13. https://doi.org/10.1016/j.compedu.2016.11.003 
Çakir, T. (2014). The attitudes of preschool teachers and principals towards computer using. The Anthropologist, 18(3), 735-744. https://doi.org/10.1080/09720073.2014.11891604

Carpi, T., \& lacus, S. M. (2020). Is Japanese gendered language used on Twitter? A large scale study. Online Journal of Communication and Media Technologies, 10(4), e202024. https://doi.org/10.30935/ojcmt/9141

Cavas, B., Cavas, P., Karaoglan, B., \& Kisla, T. (2009). A study on science teachers' attitudes toward information and communications technologies in education. Online Submission, 8(2), 1-13.

Chou, C. (2003). Incidences and correlates of Internet anxiety among high school teachers in Taiwan. Computers in Human Behavior, 19(6), 731-749. https://doi.org/10.1016/S0747-5632(03)00010-4

Chua, S. L., Chen, D. T., \& Wong, A. F. (1999). Computer anxiety and its correlates: a meta-analysis. Computers in human behavior, 15(5), 609-623. https://doi.org/10.1016/S0747-5632(99)00039-4

Cohen, J. (2013). Statistical power analysis for the behavioral sciences. Academic press. https://doi.org/10.4324/9780203771587

Collis, B. (1999). Designing for differences: Cultural issues in the design of WWW-based course-support sites. British Journal of Educational Technology, 30(3), 201-215. https://doi.org/10.1111/1467-8535.00110

Compeau, D. R., \& Higgins, C. A. (1995). Computer self-efficacy: Development of a measure and initial test. MIS Quarterly, 19(2), 189-211. https://doi.org/10.2307/249688

Davies, M. W. (2004). Women clerical workers and the typewriter: The writing machine. In Technology and Women's Voices (pp. 34-43). Routledge.

Deniz, L. (2007). Prospective class teachers' computer experiences and computer attitudes. International Journal of Social Sciences, 2(2), 116-122.

Denson, B. (2005). Teacher attitudes toward technology (Doctoral dissertation, Tennessee State University).

DerSimonian, R., \& Laird, N. (1986). Meta-analysis in clinical trials. Controlled Clinical Trials, 7(3), 177-188. https://doi.org/10.1016/0197-2456(86)90046-2

Eagly, A. H., \& Chaiken, S. (1998). Attitude structure and function. The Handbook of Social Psychology, 1(2), 269-322.

Edison, S. W., \& Geissler, G. L. (2003). Measuring attitudes towards general technology: Antecedents, hypotheses and scale development. Journal of Targeting, Measurement and Analysis for Marketing, 12(2), 137-156. https://doi.org/10.1057/palgrave.jt.5740104

Eichenold, D. K. (2008). Technology integration in Texas high school mathematics classes (Doctoral dissertation, University of Houston).

Embi, R. (2007). Computer anxiety and computer self-efficacy among accounting educators at Universiti Teknologi MARA, Malaysia (Doctoral dissertation, Virginia Tech).

Fernández Batanero, J. M., \& Bermejo Campos, B. (2012). Actitudes docentes hacia las TIC en centros de buenas prácticas educativas con orientación inclusiva [Teaching attitudes towards ICT in centers of good educational practices with an inclusive orientation]. Enseñanza \& Teaching: Journal Interuniversitaria de Didáctica, 30(1), 45-61.

González Sanmamed, M., Sangrà, A., \& Muñoz-Carril, P. C. (2017). We can, we know how. But do we want to? Teaching attitudes towards ICT based on the level of technology integration in schools. Technology, Pedagogy and Education, 26(5), 633-647. https://doi.org/10.1080/1475939X.2017.1313775

Halder, S., \& Chaudhuri, S. (2011). Computer self-efficacy and computer anxiety of trainee teachers: Issue of concern. Proceedings of Episteme, 4, 1-7. 
Hammack, R., \& Ivey, T. (2017). Examining elementary teachers' engineering self-efficacy and engineering teacher efficacy. School Science and Mathematics, 117(1-2), 52-62. https://doi.org/10.1111/ssm.12205

Hedges, L., \& Olkin, I. (1985). Statistical methods for meta-analysis. Academic.

Helms, D. (2004). First-and second-year K-12 teachers' computer self-efficacy beliefs and level of technology implementation (Doctoral dissertation, Pepperdine University).

Higgins, J. P., Thompson, S. G., Deeks, J. J., \& Altman, D. G. (2003). Measuring inconsistency in meta-analyses. Bmj, 327(7414), 557-560. https://doi.org/10.1136/bmj.327.7414.557

Hong, K. S., \& Koh, C. K. (2002). Computer anxiety and attitudes toward computers among rural secondary school teachers: A Malaysian perspective. Journal of Research on Technology in Education, 35(1), 2748. https://doi.org/10.1080/15391523.2002.10782368

Islahi, F. (2019). Exploring teacher attitude towards information technology with a gender perspective. Contemporary Educational Technology, 10(1), 37-54. https://doi.org/10.30935/cet.512527

Jegede, P. O. (2007). Factors in computer self-efficacy among Nigerian college of education teachers. Journal of Psychology in Africa, 17(1-2), 39-44. https://doi.org/10.1080/14330237.2007.10820142

Johnson, S.J. (2001). Faculty attitudes toward educational technology: An extension of Bullard's analysis of selected variables (Doctoral dissertation, Nova Southeastern University).

Kabataş, S., \& Karaoğlan Yılmaz, F. G. (2018). Öğretmenlerin yaşam boyu öğrenme tutumlarının eğitim teknolojileri standartlarına yönelik öz-yeterlikleri açısından değerlendirilmesi [Evaluation of teachers' lifelong learning attitudes in terms of selfefficacy towards the standards of educational technology]. Bartın Üniversitesi Eğitim Fakültesi Dergisi, 7(2), 588-608. https://doi.org/10.14686/buefad.405661

Kagima, L. K., \& Hausafus, C. O. (2000). Integration of electronic communication in higher education: Contributions of faculty computer self-efficacy. The Internet and Higher Education, 2(4), 221-235. https://doi.org/10.1016/S1096-7516(00)00027-0

Kahraman, S., \& Yilmaz, Z. A. (2018). In-service teachers' internet self-efficacy: A re-examination of gender differences. Turkish Online Journal of Distance Education, 19(2), 72-85. https://doi.org/10.17718/tojde.415675

Kemp, C.R. (2002). Urban school teachers' self-efficacy beliefs and practices, innovation practices, and related factors in integrating technology (Doctoral dissertation, Indiana University of Pennsylvania).

Kiliç, D. B. Ç. (2015). Music teachers computer anxiety and self-efficacy. Educational Research and Reviews, 10(11), 1547-1559. https://doi.org/10.5897/ERR2015.2235

Kilinc, E., Kilinc, S., Kaya, M., Başer, E., Türküresin, H. E., \& Kesten, A. (2016). Teachers' attitudes toward the use of technology in social studies teaching. Research in Social Sciences and Technology, 1(1), 59-76. https://doi.org/10.46303/ressat.01.01.3

Kpolovie, P. J., \& Awusaku, O. K. (2016). ICT adoption attitude of lecturers. European Journal of Computer Science and Information Technology, 4(5), 9-57.

Kretschmann, R. (2015). Physical education teachers' subjective theories about integrating Information and Communication Technology (ICT) into physical education. Turkish Online Journal of Educational Technology-TOJET, 14(1), 68-96.

Lee, C. H., Cook, S., Lee, J. S., \& Han, B. (2016). Comparison of two meta-analysis methods: Inverse-varianceweighted average and weighted sum of Z-scores. Genomics \& informatics, 14(4), 173-180. https://doi.org/10.5808/GI.2016.14.4.173 
Li, N., \& Kirkup, G. (2007). Gender and cultural differences in Internet use: A study of China and the UK. Computers \& Education, 48(2), 301-317. https://doi.org/10.1016/j.compedu.2005.01.007

Liao, Y. K. C. (1999). Gender differences on attitudes toward computers: A meta-analysis. In Society for Information Technology \& Teacher Education International Conference (pp. 1388-1393). Association for the Advancement of Computing in Education (AACE).

Lin, T. C., Tsai, C. C., Chai, C. S., \& Lee, M. H. (2013). Identifying science teachers' perceptions of Technological Pedagogical And Content Knowledge (TPACK). Journal of Science Education and Technology, 22(3), 325336. http://www.doi.org/10.1007/s10956-012-9396-6

Loyd, B. H., \& Gressard, C. (1984). Reliability and factorial validity of computer attitude scales. Educational and Psychological Measurement, 44(2), 501-505. https://doi.org/10.1177/0013164484442033

Marbán, J. M., \& Mulenga, E. M. (2019). Pre-service primary teachers' teaching styles and attitudes towards the use of technology in mathematics classrooms. International Electronic Journal of Mathematics Education, 14(2), 253-263. https://doi.org/10.29333/iejme/5649

Moreira-Fontán, E., García-Señorán, M., Conde-Rodríguez, Á., \& González, A. (2019). Teachers' ICT-related self-efficacy, job resources, and positive emotions: Their structural relations with autonomous motivation and work engagement. Computers \& Education, 134, 63-77. https://doi.org/10.1016/j.compedu.2019.02.007

Njiku, J., Maniraho, J. F., \& Mutarutinya, V. (2019). Understanding teachers' attitude towards computer technology integration in education: A review of literature. Education and Information Technologies, 24(5), 3041-3052. https://doi.org/10.1007/s10639-019-09917-z

Noori, A. (2019). Attitudes of Afghan EFL lecturers toward instructional technology. TechTrends, 63(2), 170178. https://doi.org/10.1007/s11528-018-0347-9

Norman, R. (1975). Affective-cognitive consistency, attitudes, conformity, and behavior. Journal of Personality and Social Psychology, 32(1), 83. https://doi.org/10.1037/h0076865

Olafare, F. O., Adeyanju, L. O., \& Fakorede, S. O. A. (2018). Colleges of Education Lecturers Attitude Towards the Use of Information and Communication Technology in Nigeria. MOJES: Malaysian Online Journal of Educational Sciences, 5(4), 1-12.

Olafare, O., Ibironke, E. S., Oladipo, T., \& Olumorin, C. O. (2020). Teachers'attitudes towards information and communication technology usage for instructional delivery. Nigerian Online Journal of Educational Sciences and Technology, 1(2), 49-56.

Olanrewaju, M. K., Musa, S., \& Kabir, Z. M. (2020). Analysis of lecturers'attitude towards integration of icts in teaching university students in yobe state, nigeria. Indonesian Journal of Science and Education, 4(1), 57-66. https://doi.org/10.31002/ijose.v4i1.2018

Onasanya, S. A., Shehu, R. A., Oduwaiye, R. O., \& Shehu, L. A. (2010). Higher institutions lecturers' attitude towards integration of ICT into teaching and research in Nigeria. Research Journal of Information Technology, 2(1), 1-10. https://doi.org/10.3923/rjit.2010.1.10

Ostrom, T. M. (1969). The relationship between the affective, behavioral, and cognitive components of attitude. Journal of Experimental Social Psychology, 5(1), 12-30. https://doi.org/10.1016/00221031(69)90003-1

Öztürk, E. (2018). A study of primary school teachers' and Turkish language teachers' anxiety about tablet PC assisted teaching. International Education Studies, 11(6), 66-72. https://doi.org/10.5539/ies.v11n6p66 
Papaioannou, P., \& Charalambous, K. (2011). Principals' attitudes towards ICT and their perceptions about the factors that facilitate or inhibit ICT integration in primary schools of Cyprus. Journal of Information Technology Education: Research, 10(1), 349-369. https://doi.org/10.28945/1530

Pavlou, V., \& Vryonides, M. (2009). Understanding factors that influence teachers' acceptance of technology and actual computer use for teaching: the case of Greece. Mediterranean Journal of Educational Studies, 14(2), 5-25.

Phan, T., Paul, M., \& Zhu, M. (2021). The role of teaching goals and instructional technology perceptions in faculty members' technology use. Contemporary Educational Technology, 13(3), ep307. https://doi.org/10.30935/cedtech/10885

Rodríguez-Hoyos, C., Fueyo Gutiérrez, A., \& Hevia Artime, I. (2021). The digital skills of teachers for innovating in university teaching. Pixel-Bit. Revista De Medios $Y$ Educación, 61, 71-97. https://doi.org/10.12795/pixelbit.86305

Sarfo, F. K., Amankwah, F., \& Konin, D. (2017). Computer self-efficacy among senior high school teachers in Ghana and the functionality of demographic variables on their computer self-efficacy. Turkish Online Journal of Educational Technology-TOJET, 16(1), 19-31.

Scherer, R., \& Siddiq, F. (2015). Revisiting teachers' computer self-efficacy: A differentiated view on gender differences. Computers in Human Behavior, 53, 48-57. https://doi.org/10.1016/j.chb.2015.06.038

Semerci, A., \& Aydin, M. K. (2018). Examining high school teachers' attitudes towards ICT use in education. International Journal of Progressive Education, 14(2), 93-105. http://doi.org/10.29329/ijpe.2018.139.7

Shapka, J. D., \& Ferrari, M. (2003). Computer-related attitudes and actions of teacher candidates. Computers in Human Behavior, 19(3), 319-334. https://doi.org/10.1016/S0747-5632(02)00059-6

Sieverding, M., \& Koch, S. C. (2009). (Self-) Evaluation of computer competence: How gender matters. Computers \& Education, 52(3), 696-701. https://doi.org/10.1016/j.compedu.2008.11.016

Simsek, A. (2011). The relationship between computer anxiety and computer self-efficacy. Online Submission, 2(3), 177-187. https://doi.org/10.30935/cedtech/6052

Tezci, E. (2010). Attitudes and knowledge level of teachers in ICT use: The case of Turkish teachers. Journal of Human Sciences, 7(2), 19-44.

Tuncer, M. (2012). Investigation of effects of computer anxiety and internet attitudes on computer selfefficacy. International Journal of Social Science, 5(4), 205-222. https://doi.org/10.9761/jasss_156

Tweed, S. R. (2013). Technology implementation: Teacher age, experience, self-efficacy, and professional development as related to classroom technology integration (Doctoral dissertation, East Tennessee State University).

Ünal, B., Kavanoz, S., Güler, A., \& Karabulut, N. (2019). High school students' attitudes towards ICT and media tools in learning English and academic self-efficacy beliefs. RumeliDE Dil ve Edebiyat Araştırmaları Dergisi, (17), 298-308. https://doi.org/10.29000/rumelide.656758

Valdés-Cuervo, Á. A., Arreola-Olivarría, C. G., Angulo-Armenta, J., Carlos-Martínez, E. A., \& García-López, R. I. (2011). Actitudes de docentes de educación básica hacia las TIC [Attitudes of basic education teachers towards ICT]. Magis. Journal Internacional de Investigación en Educación, 3(6), 379-392.

Vega-Gea, E., Calmaestra, J., \& Ortega-Ruiz, R. (2021). Teacher perception on the use of ICT in inclusive education. Pixel-Bit. Revista De Medios Y Educación, 62, 235-268. https://doi.org/10.12795/pixelbit.90323

Velasquez, N. J. (2002). An exploration of teacher attitude, skill and tools as predictors for the integration of technology in the $K-12$ classroom (Doctoral dissertation, Nevada University). 
Whitley Jr, B. E. (1997). Gender differences in computer-related attitudes and behavior: A meta-analysis. Computers in human behavior, 13(1), 1-22. https://doi.org/10.1016/S0747-5632(96)00026-X

Williams, C.K. (2006). An investigation of attitudes of K-12 teachers toward computer technology use in schools in a rural Mississippi district (Doctoral dissertation, Mississippi State University).

Yehya, F. M., Barbar, A. M., \& Abou-Rjeily, S. (2019). Lebanese secondary physics teachers' attitudes towards the use of ICT. International Journal of Learning and Teaching, 11(1), 8-27. https://doi.org/10.18844/ijlt.v11i1.3891

Zyad, H. (2016). Integrating computers in the classroom: Barriers and teachers' attitudes. International Journal of Instruction, 9(1), 65-78. https://doi.org/10.12973/iji.2016.916a

Correspondence: Francisco D. Guillén-Gámez, University of Cordoba, Faculty of Education, Department of Didactics and School Organization, Spain. E-mail: dguillen@uco.es 